Fatma Sultan ÖZTOPRAK ${ }^{1}$

Orcid: 0000-0003-0971-5419

Emel EGE 2

Orcid: 0000-0002-5640-5563

Necmettin Erbakan Üniversitesi Meram Tıp Fakültesi Hastanesi, Kadın Doğum Servisi Konya-Türkiye

${ }^{2}$ Necmettin Erbakan Üniversitesi Hemşirelik Fakültesi Konya-Türkiye

Sorumlu Yazar (Correspondence Author):

Fatma Sultan ÖZTOPRAK

fsultanoztprk@gmail.com

\section{Anahtar Sözcükler:}

Kanser; kanser bilgi yükü; sağlıklı yaşam biçimi.

\section{Key Words:}

Cancer; cancer information overload; healthy lifestyle.

\section{Kadın İşçilerin Kanser Bilgi Yükü ile Sağlıklı Yaşam Biçimi Davranışları İlişkisinin İncelenmesi}

\author{
Investigation of the Relationship Between Cancer Information \\ Overload and Healthy Lifestyle Behaviors of FemaleWorkers
}

*Bu çalışma yüksek lisans tez çalışması olarak hazırlanmıştır.

Başvuru Tarihi: 10.12.2020 Kabul Tarihi: 05.07.2021

ÖZ

Amaç: Bu çalışma kadın işçilerin kanser bilgi yükü ile sağlıklı yaşam biçimi davranışları ilişkisinin incelenmesi amacıyla yapılmıştır.

Yöntem: Araştırma tanımlayıcı ve ilişki arayıcı türde Karaman il merkezinde bulunan vardiya sistemi ile çalışan kadın iş̧ilerle yapılmıștır. Fabrikalardaki kadın iş̧̧i sayıları kurum politikası gereği gizli tutulmuştur. Bu nedenle toplam kadın işçi sayısına ulaşılamamıştır. $\mathrm{Bu}$ araştırma 380 kadın işçi ile tamamlanmıştır. Veriler araştırmacı tarafından hazırlanan Anket Formu, Kanser Bilgi Yükü Ölçeği ve Sağlıklı Yaşam Biçimi Davranışları II Ölçeği ile toplanmıştır. Veri analizinde Pearson korelasyon analizi, $t$ testi ve Mann Whitney U testi kullanılmıştır. Kadınların kanser bilgi yükü ve sağlıklı yaşam biçimi davranışları puanları üzerine primer analizlerde etkisi bulunan bağımsız değişkenler çoklu regresyon analizi ile değerlendirilmiştir.

Bulgular: Kadın işçilerin \%70.6's1 31 yaş ve üzerinde olup, \% 51.3'ü okuryazar/ilköğretim düzeyinde eğitim almıştır. Katılımcıların \%95.3'ü kanser tarama testlerini duymuş olup, \%57.9'u sağlık çalıșanlarından duyarken \%42.1'i basın/yayından duymuştur. Kadın işçilerin Kanser Bilgi Yükü Ölçeği puan ortalaması 19.32 \pm 5.38 , Sağlıklı Yaşam Biçimi Davranışları Ölçeği puan ortalaması 119.14 \pm 22.29 'dur. Kadın işçilerin Kanser Bilgi Yükü Ölçeği puanları ile Sağlıklı Yaşam Biçimi Davranışları Ölçeğinin beslenme, manevi gelişim ve kişiler arası ilişkiler alt boyut puanları arasında zayıf düzeyde ve pozitif yönde anlamlı bir ilişki olduğu belirlenmiştir $(\mathrm{p}<0.05)$.

Sonuç: Kadın işçilerin kanser bilgi yükü arttıkça sağlıklı yaşam biçimi davranışlarından beslenme, manevi gelişim ve kişiler arası ilişkilerinin de arttığı sonucuna varılmıştır.

\begin{abstract}
Objective: This study was conducted to examine the relationship between cancer knowledge burden and healthy lifestyle behaviors of female workers.

Methods: The research was conducted with a descriptive and relationship seeking female workers working in the shift system in the city center of Karaman. The number of female workers in the factories has been kept confidential as per the corporate policy. For this reason, the total number of female workers could not be reached. This research was completed with 380 women workers. The data were collected using the Questionnaire Form, Cancer Information Overload Scale and Healthy Lifestyle Behaviors II Scale prepared by the researcher. Pearson correlation analysis, $t$ test and Mann Whitney $U$ test were used in data analysis. Independent variables that had an effect on women's cancer knowledge overload and healthy lifestyle behavior scores in the primary analyzes were evaluated by multiple regression analysis.

Results: \%70.6 of female workers are 31 years old and over, \%51.3 of them have received education at the literate/primary level. $\% 95.3$ of the participants heard about cancer screening tests, while \%57.9 heard from healthcare professionals, $\% 42.1$ heard from the press/broadcast. Cancer Information Overload Scale mean score of female workers is $19.32 \pm 5.38$, Healthy Lifestyle Behaviors II Scale mean score is $119.14 \pm 22.29$. It was determined that there was a weak and positive significant relationship between the Cancer Information Overload Scale scores of female workers and the nutrition, spiritual development and interpersonal relations sub-dimension scores of the Healthy Lifestyle Behaviors II Scale $(\mathrm{p}<0.05)$.

Conclusion: It was concluded that as the cancer knowledge load of female workers increased, healthy lifestyle behaviors such as nutrition, spiritual development and
\end{abstract} interpersonal relations also increased. 


\section{GíRiş}

Kanser, organ veya dokudaki hücrelerin kontrolsüz bölünüp çoğalmasıyla oluşan anormal hücrelerden oluşur ve vücudun her bölümünü etkileyebilir. Kardiyovasküler hastalıklardan sonra ikinci sırada önde gelen ölüm nedeni kanserdir. Dünya sağlık örgütünün 2018 yılındaki verilerine göre 18.1 milyon kişinin kanser tanısı aldığı ve 9.6 milyon kişinin kanser sebebi ile hayatını kaybettiği tahmin edilmektedir (WHO, 2018). Globocan'ın verilerine göre kadınlarda en sık görülen kanser meme kanseridir ve kanser tanısı konulan her 4 kadından 1'i meme kanseridir. Meme kanseri en sık teşhis edilen kanser türüdür. Serviks kanseri sonucu görülen ölümlerin büyük çoğunluğu Sahra Altı Afrika ve Güney Doğu Asya'dadır. En yüksek insidans ve mortalite oranları Afrika'da görülmektedir. Dünya'da erkeklerde en sık görülen kanserler arasında kolorektal kanser üçüncü sıradadır. Kadınlarda ise meme kanserinden sonra en sık görülen kanser kolorektal kanserdir (Globocan, 2018). Türkiye'de Sağlık Bakanlığı 2017 verilerine göre kadınlarda en sık görülen (\%43) kanser meme kanseridir. Sağlık bakanlığının 2013 yılı kanser istatistiğine göre serviks kanser taramaları yurt genelinde $\% 23$ oranında artarak yaklaşık 2,5 milyona ulaşmıştır. Türkiye' de kolorektal kanserler hem kadınlarda hem de erkeklerde üçüncü sırada yer almaktadır. Erkeklerde yüz binde 22,8, kadınlarda ise yüz binde 13,8'dir (Türkiye Kanser İstatistikleri, 2017). Kanser, dünya çapında önemli bir halk sağlığı sorunudur. Küresel olarak 6 ölümden bir tanesi kanserden kaynaklanmaktadır (Siegel ve diğerleri, 2018).

Kanser erken teşhis ve tarama programlarına yönelik toplumda farkındalık oluşturmak önemlidir. Toplumdaki tüm bireyler kanserin nedenini, oluşturan risk faktörlerini ve belirtilerini doğru ve güvenilir kişilerden öğrenmelidir. Yapılan araştırma sonuçlarında katılımcıların kanser taramalarıyla ilgili bilgileri yeterli düzeyde değildir (Bayçelebi ve diğerleri, 2015; Erdem ve diğerleri, 2017; Ersin ve diğerleri, 2017). Katılımcılar kanser taramasını yaptırmayı isteseler bile ne yapılması gerektiğini bilmedikleri için tarama yaptıramamaktadırlar (Tekpınar ve diğerleri, 2018). Kanser isminin oluşturduğu endişe ile bazı kişiler erken tarama yaptırmak istemekte bazı kişiler ise tarama testlerinden uzaklaşmaktadır (Aşılar ve diğerleri 2015). Kanser erken tanı ve tarama yöntemlerini uygulayan bireylerin sağlıklı yaşam biçimi davranışları etkilenmektedir. Sağlıklı yaşam biçimi davranışları, morbidite ve mortalite oranlarını düşürmekte aynı zamanda kanserin önlenmesini sağlamaktadır (Uğur ve Avc1, 2015). Toplumda kanserin sık görülmesiyle birlikte hasta ve yakınlarının kanser hakkında bilgi alma sıklığı artmaktadır. Bilgiler genellikle sağlık çalışanı, televizyon, radyo, gazete, kitap, broşür, dergi, internet ve arkadaştan edinilmektedir (Tan ve diğerleri 2014). Güvenilir ve kaliteli bilgiye ulaşmaya çalışan bireyler doğru bilgi kaynaklarını kullanamamaktadırlar. Medyada ve diğer kaynaklarda kanser ile ilgili bilgilere ulaşmak çok kolaylaşmıştır. Kanser hakkında edinilen bilgiler tarama programlarına katılma oranını artırmaktadır. Bunun yanı sıra edinilen bilgilerin fazla olması kişilerin bilgi karmaşası yaşamasına da neden olmaktadır (Kelly ve diğerleri, 2010). Bilgi yüklemesi sorunu, kanser bilgisini arayanlar için çeşitli nedenlerden dolayı risklidir. Kanser farklı tiplerde ortaya çıkan komplike bir hastalıktır. Kanser bilgisine yönelik çalışmalar her yıl yapılmaktadır. Bilgiye erişimin artmasıyla insanlar kanser ile ilgili bilgilere daha kolay ulaşmakta ve bu durum yanıltıcı bilgi alma riskini de artırdığı için sorun oluşturmaktadır (Kim ve diğerleri, 2007). Yapılan çalışmalarda kanser bilgi yükü arttıkça kişilerin kansere yönelik bilgilerden kaçtığı ve sağlığ1 koruyucu, önleyici davranışlarının oldukça azaldığı tespit edilmiştir (Chae, 2016; Jensen ve diğerleri, 2014; Niederdeppe ve diğerleri, 2014). Güvenilir ve kaliteli bilgiye ulaşan bireylerin yaşam kaliteleri de artmaktadır (Yirmibeşoğlu ve diğerleri, 2005).

Kanserde farkındalığı artırmak ve doğru bilgiyi doğru kaynaktan öğrenebilmek için toplumun farklı kesimlerinde eğitim programları düzenlenmeli ve örneklem büyüklügüüün fazla seçildiği alanlarda çalışmalar yapılmalıdır. Ülkemizde en çok kadın çalışanı bulunan iş yerlerinden biri de fabrikalardır. Fabrikadaki çalışma ortamları işçi sağlığı üzerinde bazı riskleri barındırmaktadır. Bu nedenle çalışanların sağlıklı yaşam alışkanlıklarının incelenmesi ve işçi 
sağlığını geliştirmeye yönelik çalışmaların yapılması gerekmektedir (Kolaç ve diğerleri, 2018). Türkiye'de yapılan çalışmalar incelendiğinde kanser taramalarına yönelik bilgi durumunu araştıran birçok çalışma vardır. Ancak fabrika çalışanlarında kanser tarama yöntemlerine yönelik çalışmaya çok az rastlanılmıştır (Avcı, 2008; Yılmazel ve diğerleri, 2015). Sağlığın sürdürülmesi her ne kadar sağlık personelinin görevi olsa da bireyin kendi sorumluluğu daha da önemlidir. Sağlığı geliştirmek için olumlu davranışlar kazanmak, sağlıkla ilgili kontrolleri ihmal etmemek ve doğru bilgiyi doğru kaynaktan edinmek gerekir (İlhan ve diğerleri, 2010). Bilginin aşırı yüklenmesi etkisiz bilgi yönetimi, stres, endişe ve belirsizlik oluşturur. Bu nedenle aşırı bilgi yükü zihinsel karışıklığa sebep olup insanların gerçek bilgiye ulaşmasını engellemektedir. Geçerli ve etkin bilgilerin sağlık çalışanları tarafından verilmesi endişeyi azaltmakta, doğru bilgiyi öğretmekte, kanser erken tanı ve tarama programlarına yönelik uygulamaları artırmaktadır (Chae, 2016).

\section{YÖNTEM}

\section{Araştırmanın Amacı ve Tipi}

Araştırma kadın işçilerin kanser bilgi yükü ile sağlıklı yaşam biçimi davranışları ilişkisinin incelenmesi amacıyla tanımlayıcı ve ilişki arayıcı türde yapılmıştır.

\section{Araştırmanın Yapıldığı Yer ve Zaman}

Araştırma Karaman İl'inde bulunan iki fabrikada yapılmıştır. Bölgede çok sayıda büyük ve küçük ölçekli fabrika bulunmakla birlikte, sadece iki fabrika isimleri gizli kalmak şartı ile çalışmaya izin vermiştir. Veriler 02.08.2019-20.12.2019 tarihleri arasında toplanmıştır.

\section{Araştırmanın Evreni ve Örneklemi}

Araştırma Karaman il merkezinde bulunan vardiya sistemi ile çalışan kadın işçilerle yapılmıştır. Fabrikalardaki kadın işçi sayıları kurum politikası gereği gizli tutulmuştur. Evrene ulaşılamadığı için belirli sayıda veriye ulaşıldıktan sonra $G^{*}$ Power programı ile örneklem sayısı hesaplanmıştır. Araştırma 380 kadın işçi ile tamamlanmıştır. $\mathrm{Bu}$ çalışmanın primer sonuçlarından birisi olan, kadın işçilerin kanser bilgi yükü puanı üzerine dört bağımsız değişkenin etkili olduğu belirlenen regresyon analizinde elde edilen R2: 0.07 değerine göre $G^{*}$ Power (3.1.9.2) programı ile yapılan post hoc güç analizinde etki büyüklüğü f2: 0.08 (küçük etki) ve güç 0.995 (\%99.5) olarak bulunmuştur. Diğer primer sonuç olan, kadın işçilerin sağl1klı yaşam biçimi davranışları puanı üzerine beş bağımsız değişkenin etkili olduğu belirlenen regresyon analizinde elde edilen R2: 0.07 değerine göre $G^{*}$ Power (3.1.9.2) programı ile yapılan post hoc güç analizinde de etki büyüklüğü f2: 0.08 (küçük etki) ve güç 0.993 (\%99.3) olarak bulunmuştur. Her iki sonuç değişkenine göre de örneklem sayısının yeterli olduğu görülmüştür. Basılan 400 anket iki fabrikanın sağlık birim çalışanları tarafından kadınlara ulaştırılmış, A fabrikasından 200, B fabrikasından 180 toplam 380 anketin veri işlemeye uygun olduğu tespit edilmiştir.

\section{Araştırmada Veri Toplama Tekniği ve Araçları}

Araştırma verilerinin toplanmasında araştırmacı tarafından literatürden yararlanılarak geliştirilen Anket Formu (Duman ve diğerleri, 2015; Jensen ve diğerleri, 2014; Yiğitbaş ve diğerleri, 2017), Kanser Bilgi Yükü Ölçeği (İnci ve diğerleri, 2019) ve Sağlıklı Yaşam Biçimi Davranışları Ölçeği II kullanılmıştır (Bahar ve diğerleri, 2008). Basılan 400 anket iki fabrikanın sağlık birim çalışanları tarafından kadınlara ulaştırılmış, A fabrikasından 200, B fabrikasından 180 toplam 380 anketin veri işlemeye uygun olduğu tespit edilmiştir. Çalışma 380 kadın işçi ile tamamlanmıştır. Veriler vardiya sistemi ile A ve B fabrikası sağlık biriminde çalışan hemşireler tarafindan toplanmıştır. Fabrikada çalışan hemşirelere anket öncesi anket içerisindeki sorulara yönelik bilgi verilmiştir. Verilerin toplanmasında olasılıksız örnekleme yöntemlerinden gelişi 
güzel örnekleme yöntemi kullanılmıştır. Hemşireler tarafından kadın işçilere dağıtılan anket formları tekrar geri toplanmıştır.

\section{Soru Formu}

Literatür gözden geçirilerek araştırmacı tarafından oluşturulan soru formunda; sosyodemografik özelliklerle ilgili 5, genel sağlık özellikleri ile ilgili 4, kanser taraması bilgisine yönelik 4, meme kanseri ile ilgili 6, serviks kanseri ile ilgili 5 ve kolorektal kanser ile ilgili 3 olmak üzere toplam 26 sorudan oluşmaktadır.

\section{Kanser Bilgi Yükü Ölçeği}

Özgün ölçek ismi The Cancer Information Overload (CIO) Scale olup, Jensen ve diğerleri tarafından (2014) yılında geliştirilmiştir. Sekiz maddeden oluşan ölçek kesinlikle katılıyorum ile kesinlikle katılmıyorum arasında değişen dörtlü Likert tipi değerlendirmeye sahiptir. Kanser Bilgi Yükü Ölçeğinden en az 8, en fazla 32 puan alınabilmektedir. Özgün ölçek tek boyutludur ve kanser hastalığına ilişkin kişinin bilgi yükünü değerlendirmektedir. Ölçekten alınan puanın yüksek olması aşırı bilgi yükünü göstermektedir. Ölçeğin iç tutarlılığ 10.87 'dir. Orijinal ölçek Amerika Birleşik Devletleri'nde yetişkin örneklem grubunda geliştirilmiştir (Jensen ve diğerleri, 2014). İnci ve diğerlerinin (2019)'da Türkçe'ye uyarlayarak yaptıkları geçerlik ve güvenirlik çalışmasında, ölçeğin toplam Cronbach Alpha güvenirlik kat sayısı 0.77 olarak belirlenmiştir ve toplam puan ortalaması $18.69 \pm 4.12$ 'dir. Bu çalışmada Kanser Bilgi Yükü Ölçeğinin Cronbach alfa güvenirlik katsayısı 0.88 olarak bulunmuştur.

\section{Sağlıklı Yaşam Biçimi Davranışı Ölçeği}

Walker tarafından 1987 yılında geliştirilen sağlıklı yaşam biçimi davranışları ölçeğinin ilk versiyonu 48 madde ve altı faktörden oluşmaktadır. Ölçek 1996 yılında tekrar çalışılarak revize edilmiş ve Sağlıklı Yaşam Biçimi Davranışları Ölçeği II olarak adlandırılmıştır (Walker ve diğerleri, 1996). Sağlıklı Yaşam Biçimi Davranışları Ölçeği II, Bahar ve diğerleri (2008) tarafindan Türkçe 'ye uyarlanarak geçerlik ve güvenirlik çalışması yapılmıştır. Ölçek bireyin sağlıklı yaşam biçimi ile ilişkili olarak sağlığ 1 geliştiren davranışları ölçmektedir. Ölçek toplam 52 madde ve 6 alt faktörden oluşmuştur. Alt gruplar, manevi gelişim sağlik sorumluluğu, fiziksel aktivite, beslenme, kişilerarası ilişskiler ve stres yönetimidir. Ölçeğin genel puanı sağlıklı yaşam biçimi davranışları puanını vermektedir. Ölçeğin tüm maddeleri olumludur. Derecelendirme 4'lü likert şeklindedir. Hiçbir zaman (1), bazen (2), sık sık (3), düzenli olarak (4) olarak kabul edilmektedir. Ölçeğin tamamı için en düşük puan 52, en yüksek puan 208 'dir. Ölçeğin Alpha güvenirlik katsayıs1 0.94 'dir. Ölçeğin alt faktörlerinin Alpha coefficientreliability değeri 0.790.87 arasında değişmektedir (Walker ve diğerleri, 1996). Bahar ve diğerlerinin (2008) yaptı̆̆1 araştırmada, ölçeğin toplam Cronbach Alpha güvenirlik kat sayısının 0.92 olduğu belirlenmiştir ve toplam puan ortalaması 0.30 ile 0.59'dur. Bu çalışmada Sağlıklı Yaşam Biçim Davranışları Ölçeğinin Cronbach alfa güvenirlik katsayısı tüm ölçek için 0.94 olarak bulunmuştur. Alt boyutların Cronbach alfa güvenirlik katsayısı sağlık sorumluluğu için 0.80 , fiziksel aktivite için 0.82 , beslenme için 0.66 , manevi gelişim için 0.80 , kişiler arası ilişkiler için 0.77 , stres yönetimi için 0.74 olarak bulunmuştur.

\section{Araştırmanın Değişkenleri}

Araştırmanın Bağımlı Değişkenleri: Fabrikada çalışan kadın işçilerin kanser bilgi yükü düzeyi ve sağlıklı yaşam biçimi davranışları düzeyidir.

Araştırmanın Bağımsız Değişkenleri: Kadın işçilerin sosyo-demografik özellikleri, genel sağlık özellikleri, kanser taraması bilgi düzeyi, meme kanseri bilgi düzeyi, serviks kanseri bilgi düzeyi ve kolorektal kanser bilgi düzeyidir. 


\section{Verilerin Değerlendirilmesi}

Çalışmanın tanımlayıcı istatistiklerinde sayı, yüzde, puan düzeyi ve standart sapma verilmiştir. Sayısal verilerin normal dağılıma uygunluğu için; normallik testinde örneklem $>50$ olduğundan Kolmogorov-Smirnov testi ( $p>0.05)$, histogram grafiğinde normal dağ 11 lım eğrisi ve Skewness (-0.31 ile 0.78 aras1) ve Kurtosis (-0.17 ile 0.50 arasi) ile değerlendirilmiştir. Bu değerlere göre bağımlı değişkenlerin normal dağılım gösterdiği bulunmuştur. Kadınların kanser bilgi yükü puanları ile sağlıklı yaşam biçimi davranışı puanları arasındaki ilişki Pearson korelasyon analizi ile değerlendirilmiştir. Bağımsız değişkenlerin bağımlı değişkenlere göre analizinde normallik analizi dikkate alınarak t testi, Mann Whitney $U$ testi, tek yönlü varyans (=ANOVA) analizi (ileri analizi Tukey HSD) ve Kruskal Wallis testi (ileri analizi Bonferroni düzeltmeli Mann Whitney U testi ve Tukey HSD) kullanılmıştır. Kadınların kanser bilgi yükü ve sağlıklı yaşam biçimi davranışları puanları üzerine primer analizlerde etkisi bulunan bağımsız değişkenler çoklu regresyon (bacward yöntemi) analizi ile değerlendirilmiştir. Önemlilik düzeyi $\mathrm{p}<0.05$ olarak kabul edilmiştir.

\section{Araştırmanın Etik Yönü}

Araştırma için Necmettin Erbakan Üniversitesi İlaç ve Tıbbi Cihaz Dışı Araştırmaları Etik Kurul Başkanlığı'ndan 12.07.2019 tarihli ve 2019/2007 sayılı etik kurul izni alınmıştır. Araştırmanın yapılacağı her iki fabrikadan yazılı izin alınmıştır. Kanser Bilgi Yükü Ölçeği ve Sağlıklı Yaşam Biçimi Davranışları II Ölçeğinin çalışmada kullanılabilmesi için ölçek yazarlarından yazılı izin alınmıştır. Veri toplama formunun başına araştırmanın yapılma amacı, süresi, kimlik bilgilerinin gizli kalacağı ve gönüllü katılımın önemi ile ilgili gerekli açıklamanın bulunduğu bir metin oluşturulmuştur. Çalışmayı uygulayacak olan iş yeri hekim ve hemşirelerine çalışma hakkında bilgi verilmiştir. Veriler iş yeri hemşireleri tarafından gönüllü olarak toplanmıştır.

\section{BULGULAR}

Araştırma kapsamına alınan kadın işçilerin \%35.3'ünün 31-40 yaş arasında, \%51.3'ünün okuryazar/ilköğretim eğitim düzeyinde, \%79.2'sinin evli, \%75.8'inin çocuk sahibi olduğu belirlenmiştir. Kadın işçilerin \%53.4'ü 6 yıl ve üzeri fabrikada çalışmakta ve \%61.3'ünün geliri giderinden azdır. Kadın işçilerin \%37.4'ünün ailesinde kanser tanısı almış birey vardır. Ailesinde kanser tanısı almış birey ile birinci derece yakınlığı olan kadın işçilerin oranı \%62 olarak bulunmuştur. Araştırmaya alınan kadın işçilerin \%95.3'ü kanser tarama testlerini duymuştur. Kadın işçilerin \%57.9'u kanser tarama testlerini sağlı personelinden, \%42.1'i basın/yayından duymuştur (Tablo 1).

Katılımcıların meme kanseri taramasına ilişkin bilgi ve uygulamaları şu şekildedir: Kadın işçilerin \%70.3'ünün kendi kendine meme muayenesini (KKMM) bilmek ve \%54.2'si KKMM yapmaktadır. Katılımcıların KKMM yapmama nedenleri olarak kadınların \%49.5'i muayene yapmayı bilmediğini, \%24.7'si ihmal ettiğini, \%14.9'u ele gelen kitleden korktuğunu ve \%10.9'u işlemi gereksiz bulduğunu belirtmiştir. Araştırmaya alınan kadın işçilerin \%56.8'i mamografi işlemini bildiğini ancak sadece \%17.1'i mamografi işlemini yaptırdığını belirtmiştir. Katılımcıların mamografi işlemini yaptırmama nedenleri olarak kadınların \%41.7'si mamografi işlemini bilmediğini, \%29.8'i ihmal ettiğini, \%16.5'i kitle çıkmasından korktuğunu, \%7.6's1 gereksiz bulduğunu ve \%4.4'ü ağrılı bir işlem olduğu için yaptırmadığını belirtmiştir (Tablo 2).

Katılımcıların serviks kanseri taramasına ilişkin bilgi ve uygulamaları şu şekildedir: Çalışmaya katılan kadın işçilerin \%55.8'inin pap-smear testini bildiği, ancak \%25.5'inin papsmear testini yaptırdığı saptanmıştır. Kadın işçilerin pap-smear testini yaptırmama nedenleri olarak \%47.6'sının pap-smear testini bilmediği, \%26.9'unun ihmal ettiği, \%16.3'ünün muayene olmaktan utandığ 1 ve \%9.2'sinin kitle çıkmasından korktuğu belirlenmiştir (Tablo 2). 
Katılımcıların kolorektal kanser taramasına ilişkin bilgi ve uygulamaları şu şekildedir: Araştırmaya alınan kadın işçilerin \%44.2'sinin kolonoskopi işlemini bildiği, sadece \%4.7'sinin şuana kadar kolonoskopi işlemini yaptırdığı bulunmuştur. Kolonoskopi işlemi yaptırmama nedeni olarak kadınların \%51.9'u işlemi bilmediği, \%26.3'ü ihmal ettiği, \%14.1'i kitle çıkmasından korktuğu ve \%7.7'si muayene olmaktan utandığı belirlenmiştir (Tablo 2).

Kadın işçilerin Kanser Bilgi Yükü Ölçeği toplam puan ortalaması 19.32 \pm 5.38 , Sağlıklı Yaşam Biçimi Davranışları Ölçeği toplam puan ortalaması 119.14 \pm 22.29 olarak bulunmuştur. Sağlıklı Yaşam Biçimi Davranışları Ölçeğinin 6 alt boyutundan sağlık sorumluluğu alt boyutunun puan ortalamas1 $20.59 \pm 4.95$, fiziksel aktivite alt boyutunun puan ortalamas1 $14.64 \pm 4.60$, beslenme alt boyutunun puan ortalaması $20.41 \pm 4.26$, manevi gelişim alt boyutunun puan ortalaması $23.71 \pm 4.98$, kişiler arası ilişkiler alt boyutunun puan ortalaması $22.77 \pm 4.61$, stres yönetimi alt boyutunun puan ortalaması 17.02 \pm 4.13 olarak bulunmuştur.

Bu çalışmada kadınların Kanser Bilgi Yükü Ölçeği puanları ile Sağlıklı Yaşam Biçimi Davranışları Ölçeği puanlarının ilişkisi incelenmiştir. Kanser Bilgi Yükü Ölçeği puanları ile Sağlıklı Yaşam Biçimi Davranışları Ölçeğinin toplam puanı ve alt boyutlardan sağlık sorumluluğu, fiziksel aktivite, stres yönetimi puanları arasında istatistiksel olarak anlamlı düzeyde ilişski olmadığı saptanmıştır ( $>00.05)$. Kanser Bilgi Yükü Ölçeği puanları ile Sağlıklı Yaşam Biçimi Davranışları Ölçeğinin beslenme, manevi gelişim ve kişiler arası ilişkiler alt boyut puanları arasında zayıf düzeyde ve pozitif yönde anlamlı bir ilişki olduğu belirlenmiştir $(p<0.05)$. Kadın işçilerin Kanser Bilgi Yükü Ölçeği puanları arttıkça beslenme, manevi gelişim ve kişiler arası ilişkiler alt boyut puanları artmaktadır (Tablo 3).

Kadın işçilerin Kanser Bilgi Yükü Ölçeği ile Sağlıklı Yaşam Biçimi Davranışları Ölçeği puanı üzerine primer analizlerde etkisi olduğu belirlenen bağımsız değişkenlerin çoklu regresyon analizi ile değerlendirilmesine yönelik bulgular değerlendirilmiştir.

Kadın İşçilerin Kanser Bilgi Yükü Ölçeği Puanı Üzerine Bă̆ımsız Değişkenlerin Etkisi: Çoklu Regresyon Analizi Sonuçları: kadın işçilerin kanser bilgi yükü puanı üzerine anlamlı düzeyde etkisi olan dört değişkenin $\beta$ katsayısına göre önem sırası (en önemliden en az önemliye doğru) yaş $(p<0.001)$, manevi gelişim alt boyut puanı, kanser tarama testlerini duyma $(p<0.01)$ ve KKMM yapma $(p<0.05)$ olarak sıralanmaktadır. Söz konusu dört bağımsız değişken kadın işçilerin kanser bilgi yükü puanına ait değişimi (varyansı) \% üzerinde olan kadın işçilerin kanser bilgi yükü puanları yaş1 30 ve altında olanlara göre 2.33 puan artmaktadır. Kadın işçilerin Sağlıklı Yaşam Biçimi Davranışları Ölçeğinin manevi gelişim alt boyut puanlarındaki 1 puanlık artış kanser bilgi yükü puanını 0.16 puan arttırmaktadır. Kanser tarama testlerini basın/yayından duyan kadın işçilerin kanser bilgi yükü puanları kanser tarama testlerini hiç duymayan ve sağlı personelinden duyanlara göre 1.44 puan artmakta, kendi kendine meme muayenesi yapmayan kadın işçilerin kanser bilgi yükü puanı kendi kendine meme muayenesi yapanlara göre 1.40 puan artmaktadır (Tablo 4).

\section{Kadın İşçilerin Sağlıklı Yaşam Biçimi Davranışları Puanı Üzerine Bağımsız} Değişkenlerin Etkisi: Çoklu Regresyon Analizi Sonuçları: kadın işçilerin sağlıklı yaşam biçimi davranışları puanı üzerine anlamlı düzeyde etkisi olan beş değişkenin $\beta$ katsayısına göre önem sırası (en önemliden en az önemliye doğru) çalışma süresi, eğitim düzeyi, mamografi yaptırma, KKMM yapma ve gelir durumu $(\mathrm{p}<0.05)$ olarak sıralanmaktadır. Söz konusu beş bağımsız değişken kadın işçilerin sağlıklı yaşam biçimi davranışları puanına ait değişimi (varyansı) \% 7 olarak açıklamaktadır. Çalışma süresi beş yıldan fazla olan kadın işçilerin sağlıklı yaşam biçimi davranışları puanı çalışma süresi beş yıl ve altında olanlara göre 5.70 puan azalmaktadır. Lise ve üniversite mezunu olan kadın işçilerin sağlıklı yaşam biçimi davranışları puanı eğitimi ilköğretim ve daha az düzeyde olanlara göre 6.58 puan artmaktadır. Mamografi yaptıran kadın 
işçilerin sağlıklı yaşam biçimi davranışları puanı mamografi yaptırmayanlara göre 7.20 puan artmakta, kendi kendine meme muayenesi yapan kadın işçilerin sağlıklı yaşam biçimi davranışları puanı da yapmayanlara göre 5.15 puan artmaktadır. Geliri gidere eşit/fazla olan kadın işçilerin sağlıklı yaşam biçimi davranışları puanı geliri giderden az olanlara göre 4.44 puan artmaktadır (Tablo 5).

Tablo 1. Kadın İşçilerin Tanıtıcı Özelliklerine Göre Dağılımı

\begin{tabular}{|c|c|c|}
\hline Özellikler & $\mathbf{n}$ & $\%$ \\
\hline \multicolumn{3}{|l|}{ Yaş grubu } \\
\hline$\leq 30$ yaş & 112 & 29.5 \\
\hline $31-40$ yaş & 134 & 35.3 \\
\hline$\geq 41$ yaş & 134 & 35.3 \\
\hline \multicolumn{3}{|l|}{ Eğitim düzeyi } \\
\hline Okuryazar/ ilköğretim & 195 & 51.3 \\
\hline Ortaokul & 95 & 25.0 \\
\hline Lise ve üniversite & 90 & 23.7 \\
\hline \multicolumn{3}{|l|}{ Medeni durum } \\
\hline Evli & 301 & 79.2 \\
\hline Bekar & 79 & 20.8 \\
\hline \multicolumn{3}{|l|}{ Çocuk durumu } \\
\hline Var & 288 & 75.8 \\
\hline Yok & 92 & 24.2 \\
\hline \multicolumn{3}{|l|}{ Çalışma süresi } \\
\hline$\leq 5 \mathrm{y} 1 \mathrm{l}$ & 177 & 46.6 \\
\hline$\geq 6$ y1l & 203 & 53.4 \\
\hline \multicolumn{3}{|l|}{ Gelir durumu } \\
\hline Gelir giderden az & 233 & 61.3 \\
\hline Gelir gidere eşit/fazla & 147 & 38.7 \\
\hline \multicolumn{3}{|c|}{ Ailede kanser tanısı alma durumu } \\
\hline Var & 142 & 37.4 \\
\hline Yok & 238 & 62.6 \\
\hline \multicolumn{3}{|c|}{ Kanser tanısı alan birey ile akrabalık düzeyi (n: 142) } \\
\hline Birinci derece & 88 & 62.0 \\
\hline İkinci derece & 54 & 38.0 \\
\hline \multicolumn{3}{|c|}{ Kanser tarama testlerini duyma } \\
\hline Evet & 362 & 95.3 \\
\hline Hayır & 18 & 4.7 \\
\hline \multicolumn{3}{|c|}{ Kanser tarama testlerini duyma kaynağı (n: 362) } \\
\hline Sağlik personeli & 206 & 56.9 \\
\hline Basın/yayın & 156 & 41.1 \\
\hline
\end{tabular}


Tablo 2. Kadın İşçilerin Meme, Serviks ve Kolorektal Kanseri Taramasına İlişkin Bilgi ve Uygulamaları

\begin{tabular}{|c|c|c|}
\hline Özellikler & $\mathbf{n}$ & $\%$ \\
\hline \multicolumn{3}{|l|}{ KKMM bilme } \\
\hline Biliyor & 267 & 70.3 \\
\hline Bilmiyor & 113 & 29.7 \\
\hline \multicolumn{3}{|l|}{ KKMM yapma } \\
\hline Evet & 206 & 54.2 \\
\hline Hayır & 174 & 45.8 \\
\hline \multicolumn{3}{|l|}{$\begin{array}{l}\text { KKMM yapmama nedenleri } \\
\text { (n: 174) }\end{array}$} \\
\hline Kitle çıkmasından korkma & 26 & 14.9 \\
\hline İhmal etme & 43 & 24.7 \\
\hline Gereksiz bulma & 19 & 10.9 \\
\hline Bilgi yetersizliği & 86 & 49.5 \\
\hline \multicolumn{3}{|l|}{ Mamografi işlemini bilme } \\
\hline Biliyor & 216 & 56.8 \\
\hline Bilmiyor & 164 & 43.2 \\
\hline \multicolumn{3}{|c|}{ Mamografi işlemini yaptırma } \\
\hline Evet & 65 & 17.1 \\
\hline Hayır & 315 & 82.9 \\
\hline \multicolumn{3}{|c|}{ Mamografi işlemini yaptırmama nedenleri (n: } \\
\hline İşlemin ağrılı olması & 52 & 16.5 \\
\hline Kitle çıkmasından korkma & 94 & 29.8 \\
\hline İhmal etme & 24 & 7.6 \\
\hline Gereksiz bulma & 131 & 41.7 \\
\hline \multicolumn{3}{|l|}{ Bilgi yetersizliği } \\
\hline \multicolumn{3}{|l|}{ Pap-smear testi bilme } \\
\hline Biliyor & 212 & 55.8 \\
\hline Bilmiyor & 168 & 44.2 \\
\hline \multicolumn{3}{|l|}{ Pap-smear testi yaptırma } \\
\hline Evet & 97 & 25.5 \\
\hline Hayır & 283 & 74.5 \\
\hline \multicolumn{3}{|c|}{ Pap-smear testi yaptırmama nedenleri (n:283) } \\
\hline Kitle çıkmasından korkma & 26 & 9.2 \\
\hline Muayene olmaktan utanma & 46 & 16.3 \\
\hline İhmal etme & 76 & 26.9 \\
\hline Bilgi yetersizliği & 135 & 47.6 \\
\hline \multicolumn{3}{|l|}{ Kolonoskopi işlemini bilme } \\
\hline Biliyor & 168 & 44.2 \\
\hline Bilmiyor & 212 & 55.8 \\
\hline \multicolumn{3}{|c|}{ Kolonoskopi işlemini yaptırma } \\
\hline Evet & 18 & 4.7 \\
\hline Hayır & 212 & 95.3 \\
\hline \multicolumn{3}{|c|}{$\begin{array}{l}\text { Kolonoskopi işlemini yaptırmama nedenleri (n: } \\
\text { 362) }\end{array}$} \\
\hline Kitle çıkmasından korkma & 51 & 14.1 \\
\hline Muayene olmaktan utanma & 28 & 7.7 \\
\hline İhmal etme & 95 & 26.3 \\
\hline Bilgi yetersizliği & 188 & 51.9 \\
\hline
\end{tabular}


Tablo 3. Kadın İşçilerin Kanser Bilgi Yükü Ölçeği Puanları ile Sağlıklı Yaşam Biçimi Davranışları Ölçeği Puanlarının İlişkisi

\begin{tabular}{llcc}
\hline \multicolumn{2}{l}{$\begin{array}{l}\text { Sağlıklı Yaşam Biçimi Davranışları } \\
\text { Ölçeği }\end{array}$} & Kanser Bilgi Yükü Ölçeği & $\mathbf{p}$ \\
\hline SYBDÖ Toplam Puan & $\mathbf{r}$ & 0.093 \\
& Sağlık Sorumluluğu & 0.09 & 0.187 \\
& Fiziksel Aktivite & 0.07 & 0.338 \\
& Beslenme & -0.05 & $\mathbf{0 . 0 1 6}$ \\
& Manevi Gelişim & $\mathbf{0 . 1 2}$ & $\mathbf{0 . 0 1 3}$ \\
& Kişilerarası İlişkiler & $\mathbf{0 . 1 3}$ & $\mathbf{0 . 0 4 4}$ \\
& Stres Yönetimi & $\mathbf{0 . 1 0}$ & 0.414 \\
\hline
\end{tabular}

Tablo 4. Kadın İşçilerin Kanser Bilgi Yükü Ölçeği Puanı Üzerine Bağımsız Değişkenlerin Etkisi: Çoklu Regresyon Analizi Sonuçları (n: 380)

\begin{tabular}{|c|c|c|c|c|c|c|c|c|c|}
\hline \multirow[b]{2}{*}{ Bağımsız Değişkenler } & \multirow[b]{2}{*}{ B } & \multirow[b]{2}{*}{ S.Hata } & \multirow[b]{2}{*}{$\beta$} & \multirow[b]{2}{*}{ t } & \multirow[b]{2}{*}{ p } & \multirow{2}{*}{\multicolumn{2}{|c|}{$\begin{array}{c}\text { B için \%95 } \\
\text { Güven Aralığı }\end{array}$}} & \multicolumn{2}{|c|}{ Collinearity İstatistikleri } \\
\hline & & & & & & & & Tolerance & VIF \\
\hline (Sabit) & 7.44 & 2.09 & & 3.564 & 0.000 & 3.33 & 11.54 & & \\
\hline Yaş & 2.33 & 0.59 & 0.20 & 3.965 & 0.000 & 1.18 & 3.49 & 0.979 & 1.021 \\
\hline Manevi Gelişim* & 0.16 & 0.05 & 0.15 & 2.999 & 0.003 & 0.06 & .27 & 0.988 & 1.012 \\
\hline $\begin{array}{l}\text { Kanser tarama testlerini } \\
\text { duyma }\end{array}$ & 1.44 & 0.55 & 0.13 & 2.626 & 0.009 & 0.36 & 2.52 & 0.967 & 1.034 \\
\hline KKMM yарma & 1.40 & 0.54 & 0.13 & 2.589 & 0.010 & 0.34 & 2.47 & 0.969 & 1.032 \\
\hline R: 0.29 Adjusted $R^{2}: 0.07$ & F: 8.59 & p: 0.0 & & rbin Wa & on: 1.95 & & & & \\
\hline
\end{tabular}

Tablo 5. Kadın İşçilerin Sağlıklı Yaşam Biçimi Davranışları Puanı Üzerine Bağımsız Değişkenlerin Etkisi: Çoklu Regresyon Analizi Sonuçları (n: 380)

\begin{tabular}{|c|c|c|c|c|c|c|c|c|c|}
\hline \multirow{2}{*}{$\begin{array}{l}\text { Bağımsızı } \\
\text { Değişkenler }\end{array}$} & \multirow{2}{*}{ B } & \multirow{2}{*}{ S.Hata } & \multirow{2}{*}{$\beta$} & \multirow[b]{2}{*}{$\mathbf{t}$} & \multirow[b]{2}{*}{ p } & \multirow{2}{*}{\multicolumn{2}{|c|}{$\begin{array}{c}\text { B için 95\% Güven } \\
\text { Aralığı }\end{array}$}} & \multicolumn{2}{|c|}{ Collinearity istatistikleri } \\
\hline & & & & & & & & Tolerance & VIF \\
\hline (Sabit) & 97.00 & 7.37 & & 13.168 & 0.000 & 82.52 & 111.49 & & \\
\hline Çalışma süresi & -5.70 & 2.25 & -0.13 & 2.528 & 0.012 & -10.13 & -1.27 & 0.944 & 1.059 \\
\hline Eğitim düzeyi & 6.58 & 2.63 & 0.13 & 2.504 & 0.013 & 1.41 & 11.74 & 0.955 & 1.047 \\
\hline $\begin{array}{l}\text { Mamografi } \\
\text { yaptırma }\end{array}$ & 7.20 & 3.00 & 0.12 & 2.402 & 0.017 & 1.31 & 13.10 & 0.934 & 1.071 \\
\hline KKMM yapma & 5.15 & 2.25 & 0.12 & 2.291 & 0.023 & 0.73 & 9.57 & 0.951 & 1.051 \\
\hline Gelir durumu & 4.44 & 2.25 & 0.10 & 1.974 & 0.049 & 0.02 & 8.87 & 0.992 & 1.008 \\
\hline R: 0.28 Adjus & $0.07 \mathrm{~F}$ & 6.57 & p: 0.000 & Durbin & Iatson: 1 & & & & \\
\hline
\end{tabular}

\section{TARTIŞMA}

Toplumda yaygın olarak görülen kanser hastalığında ölümlerin azaltılması için erken teşhis ve tarama önemlidir. Bilgiyi etkili yöneten bireylerin sağlığı koruyucu ve önleyici davranışları artmaktadır. Bu çalışmada kadın işçilerin meme, serviks ve kolon kanserine yönelik tarama davranışları ile kanser bilgi yükü ve sağlıklı yaşam biçimi davranışları arasındaki ilişki incelenmiştir. Toplumda kanserin sık görülmesiyle birlikte hasta ve yakınlarının kanser hakkında bilgi alma sıklı̆̆ı artmaktadır. Kadın işçilerin \%57.9'u tarama testlerini sağlık personelinden, \%42.1'i basın/yayından duymuştur. Yapılan çalışma sonuçlarında bilgiler genellikle sağlık çalışanı, televizyon, radyo, gazete, kitap, broşür, internet ve arkadaştan edinilmektedir (Yılmaz ve Aksüyek, 2012; Yılmazel ve diğerleri, 2015; Şeker ve diğerleri, 2017). Yapılan çalışma ile 
bulguların benzer olduğu ve sağlık çalışanlarının doğru bilgiye ulaşmada anahtar bir role sahip olduğu söylenebilir. Kanserde farkındalığı artırmak için doğru bilgiyi doğru kaynaktan öğrenmek önemlidir.

Çalışma sonucuna göre kadın işçilerin kendi kendine meme muayenesi yapma ve mamografi gibi meme kanserine yönelik tarama davranışlarının sıklığı yeterli düzeyde bulunmamıştır. Meme kanseri tarama programları ile ilgili kadınların bilgisinin olduğu ancak bilginin eyleme dönüşmesi noktasında bu oranların düşük olduğu görülmüştür. Meme kanseri tarama davranışlarından kendi kendine meme muayenesi yapma ve mamografi yaptırma davranışlarının incelendiği birçok çalışmada meme kanserine yönelik tarama davranışlarının yetersiz olduğu görülmektedir. Tarama yöntemlerine karşı ön yargılar vardır ve bu ön yargıların en önemli nedenleri kitle bulma korkusu, işlemleri gereksiz bulma, ihmal etme, ağrılı işlem olduğunu düşünme ve tarama ile ilgili yetersiz bilgiye sahip olmaktır (Aygın ve diğerleri, 2004; Chee ve diğerleri, 2003; Duman ve diğerleri, 2015; Günay ve Beşer, 2011).

Çalışma sonucuna göre kadın işçilerin serviks kanserine yönelik pap-smear testi bilme durumunun yaptırma durumuna göre düşük seviyede olduğu tespit edilmiştir. Yapılan diğer çalışmalarda da kadınların pap-smear testi bilgi durumunun yetersiz olduğu görülmektedir. Kadınların pap-smaer testi yaptırmadaki engeller utangaçlık ve korku olarak belirtilmiştir (Chee ve diğerleri, 2003; Duman ve diğerleri, 2015; Işık ve diğerleri, 2016; Keshavarz ve diğerleri, 2011; Sudenga ve diğerleri, 2017; Torgbor ve diğerleri, 2017).

Çalışma sonuçlarına kolon kanserine yönelik kolonoskopi işlemini bilme durumunun yaptırma durumuna göre düşük seviyede olduğu tespit edilmiştir. Yapılan diğer çalışmalarda da kadınların kolonoskopi işlemi bilgi durumunun yetersiz olduğu görülmektedir. Kolorektal kanser taramalarını yaptırmama nedeni bilgisizlik, risk olmadığı için yaptırmama, sonucundan korkma, zaman yetersizliğidir (Pirinççi ve diğerleri, 2015; Şahin ve diğerleri, 2015; Yiğitbaş ve diğerleri, 2017). Çalışma sonuçlarına göre kolorektal kanser taramalarına yönelik bilgi durumu ve yaptırma oranı düşük seviyededir. Bireylerin çoğunluğunun işlem hakkında yeterli bilgiye sahip olmadığı, bilgisi olanların da utanma ve korku nedeniyle işlemden kaçındıkları sonucuna varılmıştır.

Kadın işçilerin kanser bilgi yükü puan ortalaması $19.32 \pm 5.38$ bulunmuştur. Kanser bilgi yükü ölçeğinden alınabilecek puan en az 8, en fazla 32'dir (Jensen ve ark. 2014). Bu konuda literatür bilgisi sınırlıdır. Çalışma sonucu değerlendirildiğinde kadın işçilerin kanser bilgi yükü orta düzeyde olduğu düşünülebilir. Kanser ile ilgili bilgiler belirsizlik uyandırır.

Kanserin nedeni ve tedavisi karmaşıktır. Bireyler kanser ile ilgili bilgileri öğrendikçe kaygılanır. Kanser bilgi yükü olumsuzluğa neden olduğu için önemli bir araştırma konusudur. Ancak kanser bilgi yükü ile ilgili araştırmalar yetersizdir. Kanser bilgi yükünü eğitim düzeyi, kayg1 durumu, ailesinde kanser öyküsü olanlar ve kanser ile ilgili edinilen bilgi kaynakları etkilemektedir (Chae ve diğerleri, 2016). Hastaların olumlu hastalık algısı arttıkça öz-bakım gücü de artmaktadır (Küçükkaya ve Erçel, 2019). Kadın işçilerin Sağlıklı Yaşam Biçimi Davranışları Ölçeği puan ortalaması 119.14 \pm 22.29 'dur. Sağlıklı Yaşam Biçimi Davranışları Ölçeğinden alınabilecek en yüksek puan 208'dir (Bahar ve diğerleri, 2008).Fabrika çalışanlarında sağlıklı yaşam biçimi davranışı ve sağlık algısının incelendiği bir çalışmada çalışanların puan ortalaması $130.70 \pm 21.98$ ' dir (Kolaç ve diğerleri, 2018). Fabrika çalışanlarında

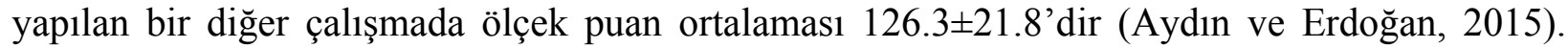
Y1lmazel ve diğerleri (2015), bir sanayi kuruluşunda yaptığı çalışmada ölçek puan ortalaması $126.00 \pm 20.28$ 'dir. Çalışma sonuçları değerlendirildiğinde işçilerin orta düzeyde sağlıklı yaşam biçimi davranışları olduğu söylenebilir. Çalışma sonuçlarına göre Sağlıklı Yaşam Biçimi Davranışları Ölçeğinin alt grupları değerlendirildiğinde puan ortalamaları sırayla şu şekildedir: Sağlık sorumluluğu 20.59 \pm 4.95 , fiziksel aktivite $14.64 \pm 4.60$, beslenme $20.41 \pm 4.26$, manevi 
gelişim $23.71 \pm 4.98$, kişilerarası ilişkiler $22.77 \pm 4.61$, stres yönetimi $17.02 \pm 4.13$ 'dür. Araştırma sonucuna göre ölçek alt grupları arasında en yüksek puan manevi gelişim, en düşük puan fiziksel aktivitedir. Fabrika çalışanlarında yapılan bir çalışmanın sonuçlarına göre ölçek alt grupları arasında en yüksek puan manevi gelişim, en düşük puan fiziksel aktivitedir (Kolaç ve diğerleri, 2018; Küçük, 2016; Yılmazel ve diğerleri, 2015). Çalışma sonuçlarına benzer olarak katılımcıların manevi gelişim puanları yüksektir. Stres yönetimi ve fiziksel aktivite puanları ise düşüktür. Sonuçlara göre çalışanların fiziksel aktivite yönünden yetersizlikleri vardır. Bu durumu kadın işçilerin çalışma şartlarının yoğun olmasının etkilemiş olabileceği düşünülmüştür.

Kadın işçilerin Kanser Bilgi Yükü Ölçeği puanları ile Sağlıklı Yaşam Biçimi Davranışları Ölçeğinin toplam puanı ve alt boyutlardan sağlık sorumluluğu, fiziksel aktivite, stres yönetimi puanları arasında istatiksel olarak anlamlı düzeyde bir ilişki yoktur ( $p>0.05$ ). Kadın işçilerin Kanser Bilgi Yükü Ölçeği puanları ile Sağlıklı Yaşam Biçimi Davranışları Ölçeğinin beslenme, manevi gelişim ve kişiler arası ilişkiler alt boyut puanları arasında zayıf düzeyde ve pozitif yönde anlamlı bir ilişki vardır $(\mathrm{p}<0.05)$. Kadın işçilerin Kanser Bilgi Yükü Ölçeği puanları arttıkça beslenme, manevi gelişim ve kişiler arası ilişkiler alt boyut puanları da artmaktadır. Nierdeppe ve diğerlerinin (2014), yaptığı bir çalışmada kanser bilgi yükü ile beslenme ve egzersiz arasında negatif ilişki görülmektedir. Bilgi yükü artan kişilerde kansere yönelik koruyucu davranışların azaldığı tespit edilmiştir. Kanser bilgi yükü ile ilgili yapılan bir diğer çalışmada bilgi yükü arttıkça kanser tarama davranışlarında azalma görülmektedir (Jensen ve diğerleri, 2014). Yapılan çalışmada kadın işçilerin kanser bilgi yükü arttıkça sağlıklı yaşam biçimi davranışlarının da arttığı görülmektedir. Kadınların kanser bilgi yükü ve sağlıklı yaşam biçimi davranışları değerlendirildiğinde yapılan çalışmada bu durum Nierdeppe ve diğerleri (2014) ve Jensen ve diğerleri (2014), çalışmasına göre pozitif yönde olduğu sonucuna varılmıştır. Bilgi yükü artan kadın işçilerin beslenme, manevi gelişim, kişiler arası ilişkilerde anlamlı bir ilişki vardır. Artan bilgi yüküne rağmen kadın işçilerin sağlı̆̆ koruyucu ve geliştirici davranışlarının da arttığı görülmüştür. Kanser bilgi yükü bireylerde kaygıyı arttıran bir durum olmakla birlikte, farkındalık artışı sağlamakta, sağlı̆̆ korumaya yönelik tedbirlere yönlendirmektedir. Kanser endișesi yaşayan bireyler kanserle ilgili bilgileri daha fazla aramaktadır. Kişinin sağlığıyla ilgili duyduğu endişenin sağlık bilgisi arayışı ile olumlu ilişkide olduğu bulunmuştur (Beckjord ve diğerleri, 2008; Renahy ve diğerleri, 2008). Sağlık bilgisini artıran kişilerin günlük yaşantısında yaşam kalitesini artırır, olumsuz düşüncelerini azaltır ve sağlık hizmetlerine katılımı kolaylaştırır (Jensen ve diğerleri, 2014). Çalışmamızın sonuncunda da kanser bilgi yükü arttıkça Sağlıklı Yaşam Biçimi Davranışları Ölçeğinin beslenme, manevi gelişim ve kişiler arası ilişkiler alt boyut puanları pozitif yönde anlamlı bir artış göstermiştir. Bilgi yükü arttıkça yaşanan kaygının bireylerin sağlığını olumlu etkileyebilecek, yaşam alanlarını destekleyebilecek konuları öncelediği, olumlu davranış geliştirdiği sonucuna varılmıştır.

Kadın işçilerin kanser bilgi yükü ölçeği ile sağlıklı yaşam biçimi davranışları ölçeği üzerine bağımsız değişkenlerin çoklu regresyon analiz sonuçları tartışılmıştır. Regresyon modeline alınan bağımsız değişkenler arasında korelasyon analizi ve multicollinearity istatistiklerine göre yüksek düzeyde otokorelasyon olmadığı belirlenmiştir.

Yapılan ileri analiz sonucunda kadın işçilerin kanser bilgi yükü toplam puanı üzerine yaşı 31 ve üzerinde olan kadın işçilerin, yaşı 30 ve altında olanlara göre 2.33 puan fazla ve çok ileri düzeyde anlamlı fark olduğu görülmüştür $(\mathrm{t}=3.965 ; \mathrm{p}<0.000)$. Yapılan çalışmalarda cinsiyet, yaş ve bireysel faktörler bireylerin bilgi ihtiyaçlarını etkilemektedir (Ankem, 2006; Illic ve diğerleri, 2005). Aşırı bilgi yüklemesi üzerinde yapılan bir çalışmada cinsiyet ve yaş gibi demografik değişkenlerin aşırı bilgi yüklemesi ile bağlantılı olduğu ifade edilmektedir. Yaş arttıkça aşırı bilgi yüküne eğilim artmaktadır (Akin, 1997). Çalışmada yaşı 31 ve üzerinde olan kadın işçilerin kanser bilgi yükü puanının arttığı görülmektedir. Yapılan ileri analizde ileri yaş kanser bilgi 
yükü açısından risk faktörü olarak saptanmıştır. Yaş arttıkça bireylerin bilgiye olan ihtiyaçlarının da arttığ1 ve doğru bilgiye doğru kaynaktan ulaşamayan bireylerin bilgi yüküne maruz kaldığ1 sonucuna varılmıştır. Ayrıca kanser gibi kronik hastalıkların yaş ile ortaya çıkma riskinin artması da bu sonucu destekler niteliktedir. Çalışmaya göre kadın işçilerin Sağlıklı Yaşam Biçimi Davranışları Ölçeğinin manevi gelişim alt boyut puanlarındaki 1 puanlık artış kanser bilgi yükü puanını 0.16 puan arttırmaktadır ve çok ileri düzeyde anlamlı fark olduğu görülmüştür $(\mathrm{t}=2.999$; $\mathrm{p}<0.003)$. Bilgi yükünün artması ile kadın işçilerin manevi gelişim alt boyut puanı da artmaktadır. Artan bilgi yükünün bireylerin sağlığı geliştirici davranışlarını etkilemiş olabileceği söylenebilir. Çalışmaya göre kanser tarama testlerini basın/yayından duyan kadın işçilerin kanser bilgi yükü puanları kanser tarama testlerini hiç duymayan ve sağlık personelinden duyanlara göre 1.44 puan fazla ve çok ileri düzeyde anlamlı fark olduğu görülmüştür $(t=2.626 ; p<0.009)$. Günümüzde kanser hastalığı artış göstermektedir. Bununla birlikte kanser ile ilgili bilgi arayış1 da artış göstermiştir. Bilgiler çoğunlukla sağlık personeli, televizyon, gazete, arkadaş ve internetten alınmaktadır (Tan ve diğerleri, 2014). İnternet ortamı giderek günlük yaşantımızın bir parçası haline gelmiştir. Bu durumun olumlu tarafı olduğu gibi yanıltıcı bilgi alma riskinden dolayı olumsuz tarafları da mevcuttur. Yapılan bir çalışmada medyada bilgi arayan kişilerin kanser bilgi yükü puanı daha yüksek bulunmuştur. Ancak çevrimiçi sağlık bilgisi arayan bireylerde, hekimleriyle e-posta yoluyla iletişim kuranlarda doğru bilgiye ulaşım söz konusu olacağı için olumlu sonuçların gelişeceği ifade edilmektedir (Kim ve diğerleri, 2007). Bireylerin tıbbi olan ve tıbbi olmayan kaynaklardan yaptığ taramalar kanser tarama ve önleme kararlarını etkilediği düşünülmektedir (Hornik ve diğerleri, 2013). Doğru bilgiyi doğru kaynaktan edinmek önemlidir. Güvenilir bilgi alan kişilerin yaşam kalitesi artmaktadır. Bilgileri yanlış kaynaklardan edinmekse kafa karışıklığına sebep olan bir faktördür. Bu durumun endişe düzeyini ve bilgi yükünü arttıran bir durum olduğu belirtilmektedir (Yirmibeşoğlu ve diğerleri, 2005). Yapılan çalışma sonuçları çalışma sonuçlarını desteklemektedir. Kadın işçilerin kanser tarama testlerini basın-yayından duyması ile yanıltıcı bilgi alma riski ve zihinsel karışıklıklar olabilir. Doğru bilgiyi doğru kaynaktan edinemeyen bireylerin kanser bilgi yükünün arttığı sonucuna varılmıştır. Çalışmaya göre kendi kendine meme muayenesi yapmayan kadın işçilerin kanser bilgi yükü puanı kendi kendine meme muayenesi yapanlara göre 1.40 puan fazladır ve çok ileri düzeyde anlamlı fark olduğu görülmüştür $(\mathrm{t}=2.589 ; \mathrm{p}<0.010)$. Günümüzde bilgiye erişim artmıştır. Artan bilgi bireylerin bilgiyi yorumlarken olumsuzluklar yaşamasına sebep olabilmektedir. Bu durum kanser tarama davranışlarını da etkilemiştir. Yapılan bir çalışmada kanser bilgi yükü arttıkça kansere ilişkin bilgilerden bireyler uzaklaşmaktadır (Chae ve diğerleri, 2016). Yapılan diğer çalışmalarda kanser bilgi yükü arttıkça kanseri koruyan, önleyen davranışların azaldığı ve kanser tarama davranışlarının azaldığı belirtilmiştir (Jensen ve diğerleri, 2014; Niederdeppe ve diğerleri, 2014). Çalışma sonuncunda da kanser tarama yöntemlerinden biri olan kendi kendine meme muayenesi yapma durumunda muayeneyi yapmayan kadınların kanser bilgi yükü yüksek bulunmuştur. $\mathrm{Bu}$ durumun kanser tarama programlarına katılma, erken tanı ve tedavi sürecini etkilediği görülmektedir. Kanser tarama programlarına yönelik bilgilendirmelerin doğru kaynaktan yapılması ile farkındalığın artacağı ve kaygının azalacağı söylenebilir.

Yapılan ileri analiz sonucunda çalışma süresi beş yıldan fazla olan kadın işçilerin sağlıklı yaşam biçimi davranışları puanı çalışma süresi beş yıl ve altında olanlara göre 5.70 puan düşük ve çok ileri düzeyde anlamlı fark olduğu görülmüştür $(\mathrm{t}=2.528 ; \mathrm{p}<0.012)$. Mevsimlik tarım işçilerinin sağlıklı yaşam biçimi davranışlarının belirlenmesi amacıyla yapılan bir çalışmada beş yıl ve üzerinde çalışan işçilerin iş tecrübesine göre Sağlıklı Yaşam Biçimi Davranışları Ölçeği puan ortalaması daha yüksek bulunmuştur (Göçer ve diğerleri, 2020). Y1lmazel ve diğerleri (2015), yaptığı çalışmada 10 yıl ve daha az süredir çalışan işçilerin Sağlıklı Yaşam Biçimi Davranışları Ölçeği puanı daha yüksektir. Cürcani ve diğerleri (2010), hemşirelerle yaptığı bir çalışmada çalışma süresi 1-5 yıl arasında olanların Sağlıklı Yaşam Biçimi Davranışları Ölçeği puan ortalaması daha yüksek bulunmuştur. Göçer ve diğerleri (2020), yaptığı çalışmada beş yıl 
ve üzeri çalışan işçilerin iş tecrübesinden dolayı sağlıklı yaşam biçimi davranışlarının arttığı tespit edilirken yapılan çalışmada bu durum Yılmazel ve diğerleri (2015) ile Cürcani ve diğerleri (2010) çalışmalarıyla benzer olduğu söylenebilir. Beş yıl ve altı fabrikada çalışan kadın işçilerin olumsuz etkenlerle daha az karşılaşmış olmasının bu durumu etkilemiş olduğu düşünülebilir. Çalışmaya göre lise ve üniversite mezunu olan kadın işçilerin sağlıklı yaşam biçimi davranışları puanı eğitimi ilköğretim ve daha az düzeyde olanlara göre 6.58 puan fazla ve anlamlı fark olduğu görülmüştür $(\mathrm{t}=2.504 ; \mathrm{p}<0.013)$. Mevsimlik tarım işçilerinin sağlıklı yaşam biçimi davranışlarının belirlenmesi amacıyla yapılan bir çalışmada ilkokul ve üzeri eğitim seviyesinde olanların Sağlıklı Yaşam Biçimi Davranışları Ölçeğinin alt boyutlarından olan beslenme ve kişiler arası ilişkiler puanları arasında anlamlı bir ilişki vardır $(\mathrm{p}<0.05)$ (Göçer ve diğerleri, 2020). Yılmazel ve diğerleri (2015), bir sanayi kuruluşunda yaptığı çalışmada eğitim durumu lise üzeri olan işçilerin Sağlıklı Yaşam Biçimi Davranışları Ölçeği puanını daha yüksek bulmuştur. Eğitim seviyesi arttıkça sağlıklı yaşam davranışlarının olumlu yönden etkilendiği düşünülebilir. Çalışmaya göre mamografi yaptıran kadın işçilerin sağlıklı yaşam biçimi davranışları puanı mamografi yaptırmayanlara göre 7.20 puan fazla ve anlamlı fark olduğu görülmüştür $(\mathrm{t}=2.402$; $\mathrm{p}<0.017$ ). Çalışmaya göre kendi kendine meme muayenesi yapan kadın işçilerin sağlıklı yaşam biçimi davranışları puanı da yapmayanlara göre 5.15 puan fazla ve anlamlı fark olduğu görülmüştür ( $\mathrm{t}=2.291 ; \mathrm{p}<0.023)$. Özen ve diğerleri (2013), yaptığı çalışmada kadınların meme kanserini bilme ve meme kanseri erken tanının önemli olma durumu ile Sağlıklı Yaşam Biçimi Davranışları puan ortalaması arasında anlamlı fark olduğu tespit edilmiştir $(p<0.05)$. Uğur ve Avcı'nın (2015) yaptı̆̆ı bir çalışmada kendi kendine meme muayenesi yapma durumu ve mamografi çektirme durumu ile Sağlıklı Yaşam Biçimi Davranışları Ölçeği puan ortalaması arasında anlamlın düzeyde bir fark bulunmuştur $(\mathrm{p}<0.05)$. Gözüyeşil ve diğerleri (2019), yaptığ1 çalışmada kadınların kendi kendine meme muayenesi yapma ve mamografi yaptırma durumuna göre Sağlıklı Yaşam Biçimi Davranışları Ölçeği puan ortalaması arasında anlamlı fark vardır. Yapılan çalışma ile benzer olarak kadınların kendi kendine meme muayenesi yapma ve mamografi işlemini yaptırma durumun sağlıklı yaşam biçimi davranışlarını olumlu olarak etkilediği görülmektedir. Bilgiyi eyleme dönüştürmenin bu durumu etkilemiş olabileceği düşünülmektedir. Çalışmaya göre geliri gidere eşit/fazla olan kadın işçilerin sağlıklı yaşam biçimi davranışları puanı geliri giderden az olanlara göre 4.44 puan fazla ve anlamlı fark olduğu görülmüştür ( $\mathrm{t}=1.974 ; \mathrm{p}<0.049)$. Koçoğlu ve diğerleri (2009), yaptı̆̆ 1 bir çalışmada ekonomik durumunu kötü algılayanlarda Sağlıklı Yaşam Biçimi Davranışları puanları daha düşük olduğu tespit edilmiştir. Özyazıcıoğlu ve diğerleri (2011), yaptığı çalışmada gelir düzeyi düşük olan öğrencilerin Sağlıklı Yaşam Biçimi Davranışları Ölçeği alt boyutlarından olan beslenme puanı oldukça düşük olup anlamlı bir fark olduğu belirtilmiştir $(p<0.01)$. İlhan ve diğerleri (2010), yaptığı çalışmada ekonomik durumu çok iyi olanların Sağlıklı Yaşam Biçimi Davranışları puan ortalaması anlamlı bulunmuştur $(\mathrm{p}<0.05)$. Gelir durumu iyi olan bireylerin sağlıklı yaşam biçimi davranışlarını gösteren beslenme (diyetisyene gitmek) ve fiziksel aktivite (spor salonuna gitmek) gibi sağlık davranışlarına daha çok önem verdiği söylenebilir. Gelir durumunun iyi olmasının bireylerin olumlu sağlık davranışlarını teşvik etmeye yardımcı olabileceği düşünülmektedir.

\section{SONUÇ VE ÖNERİLER}

Bu çalışma sonucunda Kadın işçilerin Kanser Bilgi Yükü Ölçeği puanları ile Sağlıklı Yaşam Biçimi Davranışları Ölçeğinin toplam puanı arasında ilişki bulunmazken, beslenme, manevi gelişim ve kişiler arası ilişkiler alt boyut puanları arasında zayıf düzeyde ve pozitif yönde anlamlı bir ilişki olduğu belirlenmiştir. Kadın işçilerin kanser bilgi yüküne yaş, manevi gelişim alt boyut puanı, kanser tarama testlerini duyma ve kendi kendine meme muayenesi yapmanın anlamlı düzeyde etkisinin olduğu ve sağlıklı yaşam biçimi davranışlarına çalışma süresi, eğitim düzeyi, mamografi yaptırma, kendi kendine meme muayenesi yapma ve gelir durumunun anlamlı düzeyde etkisinin olduğu tespit edilmiştir. 
$\mathrm{Bu}$ sonuçlar doğrultusunda; kanser erken tanı ve taramasının önemi konusunda eğitim programları düzenlenerek farkındalık oluşturulması, iş yeri hekim ve hemşirelerinin sağlıklı yaşam biçimi davranışlarını geliştirmeye yönelik işçilere eğitim ve danışmanlık hizmeti vermesi, tarama programları kapsamında kadın kanser türlerine yönelik sağlık muayeneleri ve taramaların yapılması önerilebilir. Araştırmacıların kadın işçilerin kanser bilgi yükü ve sağlıklı yaşam biçimi davranışlarının nelerden etkileneceğine ilişsin tarama ölçeklerinden faydalanmaları ve bu faktörlere yönelik müdahale araştırmaları yapılmaları önerilebilir.

\section{YAZAR KATKISI}

Çalışmanın planlanması, veri toplama aşamalarında gerekli uygulamaların gerçekleştirilmesi ile çalışmanın rapor haline getirilmesinde yazarlar eşit düzeyde katkı sağlamıştır.

\section{Çıkar Çatışması Beyanı}

Yazarların herhangi bir çıkara dayalı ilişkisi yoktur.

\section{Araştırmanın Etik Yönü}

Çalışma boyunca Helsinki Deklarasyonu kurallarına riayet edilmiştir.

\section{Maddi Destek}

Çalışmayı maddi olarak destekleyen kişi/kuruluş yoktur.

\section{KAYNAKLAR}

Akin, LK. (1997). Information overload: a multi-disciplinary explication and citation ranking within three selected disciplines: library studies, psychology/psychiatry, and consumer science: 1960-1996. (Unpublished doctoral dissertation). Texas Woman's University, Denton, Texas, USA.

Ankem, K. (2006). Factors influencing information needs among cancer patients: a metaanalysis. Library Information Science Research, 28, 7-23. doi: org/10.1016/j.lisr.2005.11.003

Aşılar, R., Köse, S., Yıldırım, A. (2015). Kadınların servikal kanser ve pap smear testine ilişkin bilgi, inanç ve davranışları. Türkiye Klinikleri J Nurs Sci, 7(2), 102-111. doi: 10.5336/nurses.2014-42620

Avc1, İ. (2008). Factors associated with breast self-examination practices and beliefs in female workers at a muslim community. European Journal of Oncology Nursing, 12, 127-133. doi:10.1016/j.ejon.2007.11.006

Aydın, Aİ., Erdoğan, KT. (2015). Fındık fabrikasında çalışan işçilerde obezite sıklığı ve sağlıklı yaşam alışkanlıklarının değerlendirilmesi. TAF Prev Med Bull, 14, 364-369.

Aygın, D., Uludağ, C., Şahin, S. (2004). Gençlerin meme kanseri ve kendi kendine meme muayenesi hakkındaki bilgi, tutum ve davranışlarının değerlendirilmesi. Hemşirelik Forumu Dergisi, 7(4), 1-6.

Bahar, Z., Beşer, A., Gördes, N., Ersin, F., Kıssal, A. (2008). Sağlıklı yaşam biçimi davranışları ölçeği II’nin geçerlilik ve güvenirlik çalışması. C.Ü. Hemşirelik Yüksekokulu Dergisi, 12(1), 1-13.

Bayçelebi, G., Aydın, F., Gökosmanoğlu, F., Tat, T., Varım, C. (2015). Trabzon'da kanser tarama testleri farkındalığ 1 . J Hum Rhythm, 1(3), 90-94.

Beckjord, EB., Finney, Rutten, LJ., Arora, NK., Moser, RP., Hesse, BW. Information processing and negative affect: Evidence from the 2003 health information national trends survey. Health Psychol, 27(2), $249-257$. doi: 10.1037/0278-6133.27.2.249

Chae, J. (2016). Who avoids cancer information? Examining a psychological process leading to cancer information avoidance. J Health Commun, 21, 837-844. doi.org/10.1080/10810730.2016.1177144

Chae, J., Lee, CJ., Jensen, JD. (2016). Correlates of cancer information overload: Focusing on individual ability and motivation. Health Communication, 31(5), 626-634. doi.org/10.1080/10410236.2014.986026

Chee, HL., Rashidah, S., Shamsuddin, K., Intan, O. (2003). Foctors Related to the Practice of Breast Self Examination (BSE) and Pap Smear Screening Among Malaysian Women Workers in Selected Electronics Factories. Erişim adresi: http://www.biomedcentral.com/1472-6874/3/3 doi: 10.1186/1472-6874-3-3 
Cürcani, M., Tan, M., Özdelikara, A. (2010). Hemşirelerin sağlıklı yaşam biçimi davranışları ve etkileyen faktörlerin belirlenmesi. TAF Preventice Medicine Bulletin, 9(5), 487-492.

Duman, N., Koçak, D., Albayrak, S., Topuz, Ş., Yılmazel, G. (2015). Kırk yaş üstü kadınların meme ve serviks kanseri taramalarına yönelik bilgi ve uygulamaları. G.O.P. Taksim E.A.H. Jaren, 1(1), 30-38. doi: $10.5222 /$ jaren.2015.030

Erdem, SS., Yılmaz, M., Yıldırım, H., Mayda, AS., Bolu, F., Durak, AA., Şener, Ö. (2017). Düzce'de yaşanların kanser ve kanser risk faktörleri hakkında bilgi düzeyi. Düzce Üniversitesi Sağllk Bilimleri Enstitüsü Dergisi, $7(1), 1-10$.

Ersin, F., Kıssal, A., Polat, P., Koca, B., Erdoğan, M. (2017). Kadın sağlı personelinin servikal kansere yönelik algıları ve bunu etkileyen faktörler. Hemşirelikte Araştırma Gelişstirme Dergisi, 18(2-3), 31-43.

Günay, E., Beşer, A. (2011). Sociodemographic characteristics of women who engage in early breast cancer diagnostic behaviors. AAOHN Journal, 59(10), 421-428.

Göçer, Ş., Mazıcıoğlu, MM., Ulutabanca, RÖ., Ünalan, D., Karaduman, M. (2020). Assessment of healthy lifestyle behaviors in travelling seasonal. Public Health 180. 149-153. doi.org/10.1016/j.puhe.2019.11.013

Gözüyeşil, E., Taş, F., Düzgün, AA. (2019). 15-49 yaş kadınlarda meme kanseri endişesi ve sağlıklı yaşam biçimi davranışlarını etkileyen faktörler. Çukurova Medical Journal, 44(4), 1215-1225. doi: 10.17826/cumj.493360

Globocan, Cancer Today , (2018). Erişim Tarihi: 25.12.2019 http://globocan.iarc.fr/Pages/fact_sheets_cancer.aspx

Hornik, R., Parvanta, S., Mello, S., Freres, D., Kelly, B., Schwartz, S. (2013). Effects of scanning-routine health information exposure-on cancer screening and prevention behaviors in the general population. $J$ Health Commun, 18(12), 1422-1435. doi:10.1080/10810730.2013.798381

İlhan, N., Batmaz, M., Akhan, L. (2010). Üniversite öğrencilerinin sağlıklı yaşam biçimi davranışları. Maltepe Üniversitesi Hemşirelik Bilim Ve Sanatı Dergisi, 3(3), 34-44.

İnci, F., Başkale, H., Ak, P. (2019). Kanser bilgi yükü ölçeği'nin Türkçeye uyarlanması, geçerlilik-güvenilirlik çalışması. Çukurova Medical Journal, 44(1), 127-135. doi: 10.17826/cumj.423997

Illic, D., Risbridger, GP., Green, S. (2005). The informed men: Attitudes ad information needs on prostate C-cancer screening. Journal of Men's Health and Gender, 2(4), 414-420. doi: 10.1016/j.jmhg.2005.10.006

Işık, O., Çelik, M., Keten, H., Dalgacı, A., Yıldırım, F. (2016). Kadın doktorların pap smear testi konusunda bilgi tutum ve davranışlarının belirlenmesi. Çukurova Medikal Journal, 41(2), 291-98. doi: 10.17826/cutf.208422

Jensen, JD., Carcioppolo, N., King, AJ., Scherr, CL., Jones, CL., Niederdieppe, J. (2014). The cancer information overload (CIO) scale: Establishing predictive and discriminant validity. Patient Educ Couns, 94, 90-96. doi.org/10.1016/j.pec.2013.09.016

Kelly, B., Hornik, R., Romantan, A., Schwartz, JS., Armstrong, K., Demichele, A., Fishbein, M., Gray, S., Hull, S., Kim, A., Nagler, R., Niederdeppe, J., Ramirez, AS., Smith, A., Wong, N. (2010). Cancer information scanning and seeking in the general population. $J$ Health Commun, 15(7), 734-753. doi:10.1080/10810730.2010.514029

Keshavarz, Z., Simbar, M., Ramezankhani. (2011). Factors for performing breast and cervix cancer screening by Iranian female workers: A qualitative-model study. Asian Pacific Journal of Cancer Prevention, 12, 15871592.

Kim, K., Lustria, M., Burke, D., Kwon, N. (2007). Predictors of cancer information overload: Findings from a national survey. Erişim adresi: http://informationr.net/ir/12-4/paper326.html

Koçoğlu, D., Akın, B. (2009). Sosyoekonomik eşitsizliklerin sağlıklı yaşam biçimi davranışları ve yaşam kalitesi ile ilişkisi. DEUHYO ED, 2(4), 145-154.

Kolaç, N., Balcı, AS., Şişman, FN., Ataçer, BE., Dinçer, S. (2018). Fabrika çalışanlarında sağlıklı yaşam biçimi davranışı ve sağlık algısı. Bakırköy Tip Dergisi, 14, 267-274. doi: 10.5350/BTDMJB.20170328092601

Küçük, E. (2016). Health perception and healthy lifestyle behaviors of female factory workers. Archives of Environmental and Occupational Health, 71, 216-221. doi.org/10.1080/19338244.2015.1058237

Küçükkaya, B., Erçel, Ö. (2019). Jiinekolojik kanserli hastalarda hastalık algısının öz-bakım gücüne etkisi. EGEHFD, 35(3):137-145.

Niederdeppe, J., Lee, T., Robbins, R., Kim, HK., Kresovich, A., Kirshenblat, D. (2014). Content and effects of news stories about uncertain cancer causes and preventive behaviors. Health Commun, 29, 332-346. doi.org/10.1080/10410236.2012.755603 
Özen, B., Zincir, H., Erten, ZK., Özkan, F., Elmalı, F. (2013). Genç kadınların meme kanseri ve kendi kendine meme muayenesi konusunda bilgi ve tutumları ile sağlıklı yaşam biçimi davranışları. J Breast Health, 9, 200-204. doi: 10.5152/tjbh.2013.33

Özyazıcıŏ̆lu, N., Kılıç, M., Erdem, N., Yavuz, C., Afacan, S. (2011). Hemşirelik öğrencilerinin sağlıklı yaşam biçimi davranışlarının belirlenmesi. Uluslararası Ínsan Bilimleri Dergisi, 8(2), 277-232.

Pirinççi, S., Benli, C., Okyay, P. (2015). Üçüncü basamak sağlık merkezine başvuranlarda kolorektal kanser tarama programı farkındalı çalışması. TAF Preventive Medicine Bulletin, 14(3), 209-214. doi: $10.5455 /$ pmb.1-1398327138

Renahy, E., Parizot, I., Chauvin, P. (2008). Health information seeking on the internet: a Double Divide? Results from a representative survey in the Paris Metropolitan Area, France, 2005-2006. BMC Public Health, 8(69), 1-10. doi:10.1186/1471-2458-8-69

Siegel, R., Miller, K., Jemal, A. (2018). Cancer Statistics, 2018. Cancer Journal For Clinicians, 68, 7-30. doi: $10.3322 /$ caac. 21442

Sudenga, S., Rositch, A., Otineo, W., Smith, J. (2013). Brief Report: Knowledge, attitudes, practices and perceived risk of cervical cancer among kenyan women. NIH-PA Author Manuscript Int J Gynecol Cancer, 23(5), 895899. doi:10.1097/IGC.0b013e31828e425c

Şahin, N., Üner, B., Aydın, M., Akçan, A., Gemalmaz, A., Dişçigil, G., Demirağ, S., Başak, O. (2015). Aydın merkez ilçede kolorektal kanser taramasına ilişkin bilgi, tutum ve engeller. Türk Aile Hekim Dergisi, 19(1), 37-48. doi: 10.15511/tahd.15.01037

Şeker, N., Yasin, Y., Özaydın, E., Çapacı, B., Okyay, P. (2017). Üçüncü basamak sağlık kuruluşundaki hemşirelerin kanser tarama programları bilgileri ile tarama testlerini yaptırma durumları. Düzce Tıp Fakültesi Dergisi, 19(1), 14-18.

Tan, A., Gibson, L., Zafar, H., Gray, S., Hornik, R., Armstrong, K. (2014). Associations between cancer-related information seeking and receiving PET imaging for routine cancer surveillance-an analysis of longitudinal survey data. Cancer Epidemiol Biomarkers Prev, 23, 481-489. doi:10.1158/1055-9965.EPI-13-0999

T.C. Sağlık Bakanlığı. Türkiye Kanser İstatistikleri. (2017). Erişim Tarihi: 02.05.2018 http://kanser.gov.tr/Dosya/ca istatistik/2014-RAPOR._uzun.pdf

Tekpınar, H., Aşık, Z., Özen, M. (2018). Aile hekimliği polikliniğine başvuran hastaların kanser taramalarına ilişkin yaklaşımlarının değerlendirilmesi. Türkiye Aile Hekimliği Dergisi, 22(1), 28-36. doi: $10.15511 /$ tahd.18.00128

Torgbor, J., King, J., Velez, I. (2017). Barriers and facilitators of cervical cancer screening practices among african immigrant women living in Brisbane Australia. European Journal of Oncology Nursing, 31, 22-29. doi.org/10.1016/j.ejon.2017.09.005

Uğur, H., Avcı, İ. (2015). Kanser tarama merkezine başvuran kadınların sağlıklı yaşam biçimi davranışlarının erken tanı bilgi ve uygulamalarına etkisi. Gümüşhane Üniversitesi Sağllk Bilimleri Dergisi, 4(2), 244-258.

Yılmaz, H., Aksüyek, H. (2012). Bursa ilinde meme kanserinin erken tanısında farkındalığın önemi-alan çalışması. The Journal of Breast Health, 8(2), 76-80.

Yılmazel, G., Naçar, M., Çetinkaya, F. (2016). Bir sanayi kuruluşunda çalışan işçilerin sağlığı geliştirme davranışları. TAF Prev Med Bull, 14, 161-170. doi:10.5455/pmb1-1410340413

Yiğitbaş, Ç., Bulut, A., Semerci, M. (2016). Bingöl devlet hastanesine başvuran yetişkinlerin kanser tarama testlerine ilişkin bilgi ve tutumları. Türk Jinekolojik Onkoloji Dergisi, 2, 29-38. Erişim Adresi: https://www.researchgate.net/publication/319180445

Yirmibeşoğlu, E., Öztürk, AS., Erkal, HŞ., Egehan, İ. (2005). Kanser hastalarının bilgi arayışında internet kullanımı. Inönü Üniversitesi Tıp Fakültesi Dergisi, 12(2), 125-128.

Walker, SN., Hill-Polerecky, DM. (1996). Psychometric evaluation of the health promoting lifestyle profile II. Unpublished manuscript, University of Nebraska Medical Center.

World Cancer Day. World Health Organization (WHO). (2018). Erişim adresi:http://www.who.int/cancer/worldcancer-day/2018/en/ 